\title{
PEMANFAATAN TEPUNG LIMBAH KEPALA UDANG DALAM RANSUM BURUNG PUYUH TERHADAP PERFORMAN, KONVERSI PAKAN DAN UMUR PERTAMA KALI BERTELUR
}

\author{
Utilization of Shrimp Head Waste Meal in Diet of Quail Bird on Performance, \\ Feed Conversion and First Age of Spawn Eggs \\ Bayu Gilang Perkasa ${ }^{1)}$, Edhy Sudjarwo ${ }^{2)}$ \\ 1) Mahasiswa Bagian Nutrisi dan Makanan Ternak, Fakultas Peternakan, Universitas Brawijaya Jalan \\ Veteran, Ketawanggede, Kec. Lowokwaru, Kota Malang, Jawa Timur 65145 \\ 2) Dosen Bagian Nutrisi dan Makanan Ternak, Fakultas Peternakan, Universitas Brawijaya Jalan Veteran, \\ Ketawanggede, Kec. Lowokwaru, Kota Malang, Jawa Timur 65145 \\ Email: bayugp68@gmail.com
}

\begin{abstract}
ABSTRAK
Tujuan dari penelitian ini adalah untuk mengetahui pengaruh tepung limbah kepala udang terhadap konsumsi pakan, pertambahan bobot badan, konversi pakan dan umur telur bertelur pertama. Penelitian yang digunakan adalah 120 burung puyuh betina, metode penelitian menggunakan empat perlakuan dan enam ulangan. Data dianalisis menggunakan ANOVA dan jika ada efek signifikan maka akan dilanjutkan oleh Uji Jarak Berganda Duncan. Tepung limbah kepala udang diberikan dengan menambahkan ke dalam pakan komersial sebanyak 1\%, 3\%, dan 6\% dari pakan. Berdasarkan hasil penelitian, pemberian tepung limbah udang memiliki pengaruh yang berbeda nyata $(P>0,05)$ terhadap konsumsi pakan dengan rata-rata 481,87 gram / burung, pertambahan bobot badan dengan rata-rata 103,09 gram/ekor. konversi unggas dan pakan dalam puyuh dengan rata-rata 5,19. Sedangkan pemberian limbah tepung kepala udang tidak memiliki pengaruh yang berbeda terhadap burung puyuh pada usia pertama kali bertelur dengan rata-rata 44,97 (45 hari).
\end{abstract}

Kata kunci: Limbah udang, burung puyuh, konsumsi pakan, pertambahan bobot badan, konversi pakan.

How to Cite:

Perkasa, B. G., \& Sudjarwo, E. (2019). Pemanfaatan Tepung Limbah Kepala Udang dalam Ransum Burung Puyuh Terhadap Performan, Konversi Pakan dan Umur Pertama Kali Bertelur. Jurnal Nutrisi Ternak Tropis 2 (2) 51-58
*Corresponding author:

Bayu Gilang Perkasa

Email: bayugp68@gmail.com

Fakultas Peternakan, Universitas Brawijaya Jalan Veteran, Ketawanggede, Kec. Lowokwaru, Kota Malang, Jawa Timur 65145 


\section{ABSTRACT}

The research aimed to determine the effect of shrimp head waste meal on the feed consumption, body weight gain, feed conversion and age at first laying eggs. The research used was 120 female quails, the study method wes using experimental desain with four treatments and six replications. The data was analyzed using ANOVA and if there were significant effect then would be continued by Duncan's Multiple Rage Test (DRMT). The shrimp head waste meal is given by adding into commercial feed as much as 1\%, 3\%, and 6\% of the feed. Based on the result of the study, it is found that the addition of shrimp head waste meal has a difference effect $(P>0.05)$ on feed consumption with an average of 481.87 grams/bird, body weight gain with an average of 103.09 grams/bird and feed conversion in quail with an average of 5.19. While giving shrimp head meal waste does not have a difference effect on quails in their age of first time laying eggs with an average of 44.97 (45 days).

Keywords: Shrimp waste, quail, feed consumption, body weight gain, feed conversion.

\section{PENDAHULUAN}

Peternakan juga memegang peranan penting dalam kesejahteraan hidup masyarakat, mulai dari usaha peternakan yang dapat menyerap tenaga kerja, ternak yang dapat memenuhi kebutuhan protein hewani sampai ke kotoran ternak yang dapat memperbaiki ekosistem lingkungan bila dikelola dengan baik dan benar. Salah satu jenis usaha ternak yang mulai berkembang pesat di Indonesia yaitu pada bidang unggas diantaranya adalah burung puyuh. Populasi puyuh pada tahun 2015,2016 dan 2017 berturut-turut adalah sebanyak 13,781,918 ekor, 14,107,687 ekor, 14,427,314 ekor (Anonimous, 2018). Peningkatan usaha peternakan puyuh ini dikarenakan puyuh memiliki banyak keunggulan dibanding ternak unggas lainnya.

Salah satu keunggulannya yaitu cepat berproduksi, pada umur 42 hari burung puyuh sudah mulai bertelur dan mengalami puncak produksi pada umur 150 hari dengan persentase bertelur $76 \%$. Pada saat ini usaha telur puyuh bukan hanya memproduksi telur saja akan tetapi juga memproduksi dagingnya (Widyatmoko, Zuprizal dan Wihandoyo, 2013). Masalah utama dalam dunia peternakan adalah tingginya biaya pakan yaitu mencapai $60-70 \%$ dari total biaya produksi (Herlinae dan Yemima, 2016). Upaya yang dapat digunakan untuk menekan biaya yang dikeluarkan oleh penyediaan pakan tersebut dengan cara mensubtansinya. Salah satu bahan pakan yang masih belum banyak digunakan yaitu tepung limbah kepala udang. Tepung limbah kepala udang memiliki kandungan protein yang cukup tinggi berkisar antara 25-50\%, tergantung pada jenis udang dan tempat hidupnya. Selain itu, limbah udang juga mengandung hampir semua jenis asam amino esensial, terutama metionin dengan jumlah dua kali lebih tinggi dari pada bungkil kedelai, tetapi lebih rendah dari pada tepung ikan (Bakrie, Sente dan Andayani 2010). Pemanfaatan tepung tepung limbah kepala udang dalam pakan perlu dilakukan penelitian selanjutnya tentang pengaruh pemberian tepung limbah kepala udang dalam pakan terhadap konsumsi pakan, pertambahan bobot badan, konversi pakan dan umur pertama kali bertelur pada burung puyuh.

\section{MATERI DAN METODE}

Materi dalam penelitian ini menggunakan ternak puyuh (Coturnix coturnix japonica) berumur 14 hari sebanyak 120 ekor. Penelitian ini menggunakan kandang koloni. Kandang koloni dibagi menjadi 24 petak dengan ukuran panjang, lebar dan tinggi 22 x 33 x $34 \mathrm{~cm}$ dan dalam satu petak berisi ternak puyuh berjumlah 5 ekor, dalam setiap kandang dilengkapi dengan tempat pakan, 
tempat minum, lampu, timbangan digital, plastik, serokan pakan dan penampung telur. Penelitian ini menggunakan pakan produksi PT. Japfa Comfeed Indonesia, Tbk yang mengandung bahan pakan diantaranya Jagung Kuning, Soy Gluten Meal, Meat and Bone Meal, Corn Gluten Meal, Wheat Bran, Plam Olein, asam amino esensial, mineral esensial, Premix dan vitamin dengan harga Rp. 350.000,-/sak (50 kg).

Metode yang digunakan dalam penelitian ini yaitu metode percobaan dengan menggunakan Rancangan Acak Lengkap (RAL) yang terdiri dari 4 perlakuan dan 6 ulangan dan setiap ulangan terdiri dari 5 ekor puyuh betina, unit percobaan berjumlah 24 unit dan ternak puyuh yang digunakan sebanyak 120 ekor. Perlakuan pada penelitian yaitu dengan memodifikasi pakan dengan menambahkan tepung limbah kepala udang dengan konsentrasi yang berbeda. Perlakuan pada pakan diantaranya sebagai berikut:

$\mathrm{P} 0$ = pakan komersil produksi PT. Japfa Comfeed Indonesia

P1 = pakan komersil yang dicampur dengan tepung limbah kepala udang 1\%

P2 = pakan komersil yang dicampur dengan tepung limbah kepala udang 3\%

P3 = pakan komersil yang dicampur dengan tepung limbah kepala udang $6 \%$

\section{HASIL DAN PEMBAHASAN}

Data hasil penelitian tentang pengaruh penambahan tepung limbah kepala udang dalam pakan terhadap variabel yang diamati yaitu konsumsi pakan, pertambahan bobot badan, konversi pakan, dan umur pertama kali bertelur selama penelitian dapat dilihat pada Tabel 2.

Tabel 1. Kandungan nutrisi pakan perlakuan

\begin{tabular}{lccccc}
\hline Kandungan Zat Makan & TLKU & P0 & P1 & P2 & P3 \\
\hline Bahan Kering (\%) & 84,75 & $98^{* *}$ & 90,54 & 90,75 & 90,58 \\
Protein Kasar* (\%) & 21,76 & $19-21^{* *}$ & $22,05^{*}$ & $23,75^{*}$ & $22,42^{*}$ \\
Serat Kasar* (\%) & 23,32 & $6^{* *}$ & $6,51^{*}$ & $5,71 *$ & $7,28^{*}$ \\
\hline
\end{tabular}

Sumber: Hasil Uji Analisis Proksimat di Laboratorium Nutrisi dan Makanan Ternak Fakultas Peternakan Universitas Brawijaya (2018)

*). Berdasarkan $100 \%$ bahan kering

**). PT Japfa Comfeed Indonesia

Tabel 2. Rataan Konsumsi Pakan, PBB, Konversi Pakan dan Umur Pertamakali Bertelur

\begin{tabular}{ccccc}
\hline Perlakuan & $\begin{array}{c}\text { Rataan } \\
\text { Konsumsi } \\
\text { Pakan (g/ekor) }\end{array}$ & $\begin{array}{c}\text { Rataan PBB } \\
\text { (g/ekor) }\end{array}$ & $\begin{array}{c}\text { Rataan } \\
\text { Konversi pakan }\end{array}$ & $\begin{array}{c}\text { Rataan Umur } \\
\text { Pertama Kali } \\
\text { Bertelur (hari) }\end{array}$ \\
\hline P0 & $482,03^{\mathrm{b}}$ & $101,77^{\mathrm{a}}$ & $4,74^{\mathrm{b}}$ & 44,83 \\
P1 & $482,17^{\mathrm{b}}$ & $103,37^{\mathrm{b}}$ & $4,66^{\mathrm{b}}$ & 44,83 \\
P2 & $482,7^{\mathrm{b}}$ & $103,9^{\mathrm{b}}$ & $4,65^{\mathrm{a}}$ & 44,17 \\
P3 & $480,57^{\mathrm{a}}$ & $103,33^{\mathrm{b}}$ & $4,65^{\mathrm{a}}$ & 46,08 \\
\hline
\end{tabular}

Keterangan: Superskrip berbeda ${ }^{(\mathrm{a}-\mathrm{b})}$ pada baris yang sama memberikan pengaruh yang berbeda nyata $(\mathrm{P}<0,05)$ 
Pengaruh Penambahan Tepung Limbah Kepala Udang dalam Pakan terhadap Konsumsi Pakan

Berdasarkan pada Tabel 2 menunjukan bahwa pemberian tepung limbah kepala udang berpengaruh nyata $(\mathrm{P}<0,05)$ terhadap konsumsi pakan. Hal ini diduga karena penggunaan tepung limbah kepala udang dalam pakan burung puyuh memberikan rasa yang berbeda dibandingkan tanpa pemberian tepung limbah kepala udang sehingga mampu meningkatkan palatabilitas dari pakan tersebut. Unggas memiliki sistem perasa yaitu lidahnya berupa gustative or taste buds yang berfungsi mengenali rasa pakan yang dikonsumsinya (Amrullah,2004).

Sedangkan indra penciuman pada unggas (olfactory system) kurang berkembang, hal itu menyebabkabkan unggas dapat merasakan bentuk, rasa, tekstur, bau, dan suhu pakan setelah pakan masuk ke dalam mulut. Avianti, Siti dan Tyas (2014) menambahkan Meskipun jumlah titik perasa pada unggas lebih sedikit dibandingkan dengan hewan lainnya akan tetapi sensivitasnya lebih tinggi.

Penambahan tepung limbah kepala udang masing-masing sebesar $1 \%$ dan $3 \%$ mampu meningkatkan konsumsi pakan dibandingkan dengan perlakuan P0 tanpa penambahan tepung limbah kepala udang. Akan tetapi, rataan konsumsi menurun pada perlakuan P3 yang menambahkan tepung limbah kepala udang sebesar $6 \%$.

Penurunan konsumsi pakan pada perlakuan P3 ini diduga karena kandungan serat kasar yang tinggi sehingga mengakibatkan turunnya rataan konsumsi pakan pada perlakuan ini. Kandungan serat kasar pada perlakuan P3 sebesar 7,28\% dan telah melebihi ambang batas yang direkomendasikan yaitu maksimal sebesar 7\%. Hal ini sesuai dengan penjelasan Bakrie, Manshur dan Sukadana (2010) bahwa kandungan serat kasar pakan yang mendekati atau melebihi ambang batas yang direkomendasikan akan menghasilkan konsumsi yang cenderung menurun.
Pengaruh Penambahan Tepung Limbah Kepala Udang dalam Pakan terhadap Pertumbuhan Bobot Badan

Penambahan tepung limbah kepala udang berpengaruh nyata $(\mathrm{P}<0,05)$ terhadap pertambahan bobot badan. Pertambahan bobot badan erat kaitannya dengan kandungan nutrisi yang dikonsumsi oleh puyuh. Semakin lengkap kandungan asam amino dan nutrisi yang lainnya maka proses pembentukan jaringan dan organ tubuh lainnya akan semakin cepat pula sehingga mengakibatkan pertambahan bobot badan yang tinggi. Hal ini di dukung dengan pendapat Mirzal (2008) bahwa di dalam tepung limbah kepala udang mengandung asam amino kritis seperti metionin, lisin, triptopan serta retensi nitrogen. Kandungan asam amino kritis ini dapat dimanfaatkan puyuh dengan baik walaupun tepung limbah kepala udang mengandung serat kasar dan terdapat zat kitin yang dapat membatasi daya cerna makanan. Goa, Silitonga, dan Yuanita (2015) dan Kaban, Mirwandhono, Hasnudi (2014) menambahkan bahwa jumlah pakan yang dikonsumsi, laju perjalanan pakan dalam saluran pencernaan, bentuk fisik pakan, komposisi pakan, dan imbangan kandungan nutrisi pakan, bangsa, jenis kelamin, energi metabolisme dan suhu lingkungan sangat mempengaruhi pertambahan bobot badan adalah kandungan protein

Hasil Uji Duncan's menunjukan bahwa penambahan tepung limbah kepala udang dengan level 1-6\% dalam pakan burung puyuh berpengaruh nyata $(\mathrm{P}<0,05)$ terhadap pertambahan bobot badan pada burung puyuh. Perlakuan P2 yang menggunakan tepung limbah kepala udang sebesar 3\% nyata lebih tinggi rataan pertambahan bobot badan burung puyuh dibandingkan dengan perlakuan tanpa ditambahkan tepung limbah kepala udang (P0), akan tetapi tidak berbeda nyata dengan perlakuan penambahan tepung limbah kepala udang $1 \%$ (P1) dan perlakuan penambahan tepung limbah kepala udang $6 \%(\mathrm{P} 3)$. 
Jumlah pakan yang dikonsumsi berkaitan erat dengan pertumbuhan bobot badan dari puyuh. Hal ini terbukti pada perlakuan $\mathrm{P} 2$ yang menghasilkan rataan konsumsi pakan tertinggi dan diikuti dengan rataan pertambahan bobot badan yang tinggi dibandingkan dengan perlakuan lain. Rataan pertambahan bobot badan yang tinggi pada perlakuan P2 diduga karena kandungan protein pada perlakuan P2 lebih tinggi dibandingkan perlakuan yang lainnya. Tingginya protein pada perlakuan P2 akan mempengaruhi kinerja pembentukan jaringan dan organ tubuh dari ternak sehingga didapatkan pertambahan bobot badan yang tinggi. Hal ini diperkuat oleh Savira, Yaman dan Jalaluddin (2018) bahwa pertambahan bobot badan adalah kemampuan puyuh dalam mengubah zat-zat makanan yang berada di dalam pakan untuk diubah menjadi daging. Pertumbuhan meliputi peningkatan ukuran sel-sel tubuh akan peningkatan sel-sel individu (Lase, Sujana, dan Indrijani, 2008).

Proses masuknya pakan dalam saluran pencernaaan dan bentuk fisik pakan juga mempengaruhi penyerapan nutrisi dari pakan untuk diubah menjadi daging. Penambahan tepung limbah kepala udang sebanyak 6\% (P3) memperlihatkan hasil yang lebih rendah dibanding dengan perlakuan yang menambahkan tepung limbah kepala udang 1\% (P1) dan 3\% (P2). Hal ini diduga karena tingginya kandungan serat kasar dan kitin pada pakan perlakuan P3 yang dapat mempengaruhi laju penyerapan nutrisi pada usus puyuh. Menurut Latif, Suprijatna dan Sunarti (2017) kandungan serat kasar yang lebih tinggi pada pakan mengakibatkan sistem pencernaan terhadap pakan lebih cepat keluar sehingga kandungan nutrisi pakan kurang tercerna dengan baik.

\section{Pengaruh Penambahan Tepung Limbah Kepala Udang dalam Pakan terhadap Konversi Pakan}

Berdasarkan hasil analisa statistik menunjukan bahwa penambah tepung limbah kepala udang memberikan perbedaan pengaruh yang nyata $(\mathrm{P}<0,05)$ terhadap konversi pakan. Hal ini diduga karena konsumsi pakan dan pertambahan bobot badan juga memberikan perbedaan pengaruh yang nyata.

Hasil uji lanjut menunjukkan bahwa dengan adanya penambahan tepung limbah kepala udang dalam pakan dapat menurunkan konversi pakan. Rataan konversi pakan tertinggi terdapat pada perlakuan P0 dengan tanpa penambahan tepung limbah kepala udang. Tingginya konversi pakan pada perlakuan P0 diduga karena rendahnya rataan pertambahan bobot badan yang dihasilkan pada perlakuan tersebut. Sedangkan pada perlakuan P1, P2 dan P3 yang menggunakan tepung limbah kepala udang masing-masing sebesar $1 \%$, $3 \%$ dan $6 \%$ dapat menurunkan konversi pakan. Hal ini sejalan dengan pendapat Mirzal (2008) yang menyatakan bahwa konversi pakan adalah perbandingan antara konsumsi pakan dengan pertambahan bobot badan.

Konsumsi pakan erat kaitannya dengan konversi pakan, dikarenakan konsumsi pakan ditujukan untuk produksi dalam hal ini pertambahan bobot badan, sehigga konversi dari pakan ini saling terkait satu sama lain antara konsumsi pakan dan bobot badan yang dihasilkan. Menurut Fahrudin, Wiwin dan Heni (2016), yang mempengaruhi konversi pakan adalah faktor seperti umur ternak, bangsa ternak, kandungan gizi pada pakan, keadaan temperatur, dan keadaan ternak, tatalaksana dan bibit yang baik. Status produksi akan berperan dalam konversi pakan dikarenakan fase dari produksi menghasilkan produksi yang berbeda dan akan mengonversi pakan menjadi produk yang berbeda pula.

Tingginya nilai konversi pakan ini dikarenakan jumlah konsumsi pakan yang rendah dan pertambahan bobot yang rendah akibat penambahan dari tepung limbah kepala udang yang banyak mengandung serat kasar dan kandungan kitin sehingga berdampak terhadap efsiensi pakan. Konversi pakan juga dapat dipengaruhi oleh keseimbangan nutrisi antara energi dan 
protein pada pakan. Energi berperan untuk membatasi konsumsi pakan, apabila jarak kandungan antar energi dengan protein yang terlalu tinggi akan menyebabkan rendahnya konsumsi protein sehingga pertumbuhan mengalami hambatan dan berpengaruh pada efisiensi penggunaan pakan (Djulardi, Muis dan Latif. 2006).

\section{Pengaruh Penambahan Tepung Limbah Kepala Udang dalam Pakan Terhadap Umur Pertama Bertelur}

Berdasarkan hasil penelitian menunjukan bahwa penambahan tepung limbah kepala udang memberikan perbedaan pengaruh yang tidak nyata $(\mathrm{P}>0,05)$ terhadap umur pertama kali bertelur. Hasil rataan umur pertama kali bertelur secara berurutan dari tertinggi sampai terendah yaitu $\mathrm{P} 0=44,83 \pm 1,25$ hari, $\mathrm{P} 1=44,83 \pm 2,07$ hari, $\mathrm{P} 2=44,17 \pm$ 1,72 hari dan $\mathrm{P} 3=46,08 \pm 2,22$. Rataan tersebut menunjukan bahwa P2 memiliki umur pertama bertelur yang paling cepat dan P3 memiliki umur pertama kali bertelur paling lama dalam penelitian ini. Hal ini diduga karena kandungan protein dalam pakan perlakuan P2 lebih tinggi dibandingkan dengan perlakuan lainnya.

Meningkatnya taraf protein ransum mengakibatkan meningkatnya konsumsi protein sehingga terjadinya peningkatan perkembangan ovarium dan folikel (Robinson, Wilson, Yu, dan Hardin. 1993). Hal tersebutlah yang menyebabkan puyuh P2 mengalami cepat bertelur dibandingkan dengan puyuh perlakuan lainnya. Sedangkan umur pertama kali bertelur paling lama pada penelitian ini ditunjukkan oleh perlakuan P3. Hal ini diduga karena semakin meningkatnya level penggunaan tepung limbah kepala udang akan menyebabkan meningkatnya kandungan zat kitin dalam pakan.

Zat kitin diketahui mampu menghambat kerja dari proses pencernaan, sehingga apabila proses pencernaan pakan terhambat maka ternak akan kesulitan memenuhi kebutuhan nutrisi baik untuk hidup pokok maupun produksinya. Hal ini didukung oleh penjelasan Bakrie, Manshur dan Sukadana (2012) bahwa zat kitin mampu membentuk ikatan dengan protein dan mineral, sehingga sulit dicerna dan berakibat pada menurunnya asupan protein bagi burung puyuh.

Umur pertama kali bertelur burung puyuh ditentukan oleh faktor konsumsi pakan serta tercapainya bobot badan yang ideal untuk masak kelamin bagi burung puyuh. Didukung oleh pendapat Zainudin, Syahruddin (2012) dan North, Bell (1990) bahwa umur pertama kali bertelur berhubungan dengan faktor makanan dan pertambahan bobot badan puyuh. Lambatnya umur induk bertelur juga disebabkan oleh genetik puyuh yang dipelihara. Puyuh pertama kali bertelur berumur antara 35 - 72 hari dengan rataan umur 41 hari (Wiradimaja 2007).

Rata-rata bobot badan burung puyuh pada penelitian ini di awal bertelur sebesar 118,01 g/ekor, sedangkan jumlah konsumsi sebanyak 136,46 g/ekor/minggu atau 19,49 g/ekor/hari. Bobot badan pada awal bertelur di penelitian ini berada pada kisaran penelitian yang dilakukan oleh Fu, Ugahara, dan Ubo (2000) yaitu 119-125 g. Lebih lanjut dijelaskan bahwa burung puyuh dengan bobot badan 90-100 g akan segera mulai bertelur. Konsumsi pakan burung puyuh pada penelitian ini sesuai dengan rekomendasi dari Listiyowati dan Roospitasari (2005) yaitu pada umur 6 minggu konsumsi burung puyuh sebanyak 17-19 g/ekor/hari.

\section{KESIMPULAN DAN SARAN}

Pada penelitian didapatkan kesimpulan yaitu penambahan tepung limbah kepala udang kedalam pakan sebanyak $3 \%$ dari pakan dapat meningkatkan konsumsi pakan, pertambahan bobot badan serta dapat menurunkan angka konversi pakan pada burung puyuh, tetapi penambahan tepung limbah kepala udang sebanyak 3\% dari pakan tidak dapat mempecepat umur pertama kali bertelur pada burung puyuh. 


\section{DAFTAR PUSTAKA}

Amrullah, I. K. (2004). Nutrisi Ayam Broiler (2nd ed.). Bogor: Lembaga Satu Gunung Budi.

Andayani, D., Yanis, M., Rahardjo, Y., Wibowo, B., \& Bakrie, B. (2000). Uji Adaptasi Teknologi Pemberian Pakan Hemat Dan Efisien Untuk Itik Petelur Di DKI Jakarta. Prosidings Seminar Nasional Pemanfaatan Teknologi Spesifik Lokasi Ekoregional Sumatera-Jawa. (LPTP Natar, Ed.). Bogor: Pusat Penelitian Sosial Ekonomi.

Anonim. (2018). Statistik Peternakan Dan Kesehatan Hewan 2017. Badan Pusat Statistik Indonesia.

Asiyah, N., Sunarti, D., \& Atmomarsono, U. (2013). Performa burung puyuh (Coturnix coturnix japonica) umur 3 sampai 6 minggu dengan pola pemberian pakan bebas pilih (Free choice feeding). Animal Agriculture Journal, 2(1), 497-502.

Aviati, V., Mardiati, S. M., \& Saraswati, T. R. (2014). Kadar kolesterol telur puyuh setelah pemberian tepung kunyit dalam pakan. Buletin Anatomi Dan Fisiologi Dh Sellula, 22(1), 5864. https://doi.org/10.14710/BAF.V22I1.7809

Bakrie, B., Manshur, E., \& Sukadana, I. M. (2017). Pemberian berbagai level tepung cangkang udang ke dalam ransum anak puyuh dalam masa pertumbuhan (umur 1-6 minggu). Jurnal Penelitian Pertanian Terapan, 12(1), 58-68. https://doi.org/10.25181/JPPT.V12I1.199
Bakrie, B., Sente, U., \& Andayani, D. (2010). Penggunaan Tepung Limbah Organik Pasar Sebagai Pengganti Dedak Dalam Ransum Ternak Itik Petelur. lampung: Universitas Lampung.

Djulardi, A., Muis, H., \& Latif, A. S. (2006). Nutrisi Aneka Ternak dan Satwa. Padang: Fakultas Peternakan Andalas.

Fahrudin, A., Wiwin, T., \& Heni, I. (2016). Konsumsi Ransum, Pertambahan Bobot Badan Dan Konversi Ransum Ayam Lokal Di Jimmy's Farm Cipanas Kabupaten Cianjur. Bandung: Universitas Padjadjaran.

Goa, S. E., Silitonga, L., \& Yuanita, I. (2015). Substitusi ransum jadi dengan roti afkir terhadap performa burung puyuh (Coturnix coturnic japonica)umur starter sampai awal bertelur. Jurnal Ilmu Hewani Tropika, 4(2), 61-65.

Herlinae, \& Yemima. (2016). Efektifitas berbagai probiotik kemasan terhadap pertumbuhan dan produksi burung puyuh (coturnix coturnix japonica). Jurnal Ilmu Hewani Tropika, 5(2), 95-100.

Kaban, S. R. E. (2016). Penggunaan tepung limbah udang dengan pengolahan filtrat air abu sekam fermentasi EM-4 dan kapang Trichoderma viride pada ransum terhadap pertumbuahan ayam broiler. Jurnal Peternakan Integratif, 2(3), 321-331.

Lase, H. G. (2016). Performa pertumbuhan puyuh (Coturnix coturnix japonica) petelur betina silangan warna bulu coklat dan hitam di pusat pembibitan puyuh universitas padjadjaran. Students E-Journal, 5(4), 1-7. 
Latif., Sukron., Suprijatna, E., \& Sunarti, D. (2017). Performans produksi telur puyuh yang diberi ransum tepung limbah udang fermantasi. Jurnal IlmuIlmu Peternakan, 27(3), 44-53. https://doi.org/10.21776/ub.jiip.2017.027.03.06

Mirwandhono, E., \& Siregar, Z. (2004). Pemanfaatan hidrolisat tepung kepala udang dan limbah kelapa sawit yang difermentasi dengan aspergillus niger, rizhopus oligosporus dan thricoderma viridae dalam ransum ayam pedaging. Sumatera Utara: Fakultas Pertanian Universitas Sumatera Utara.

Mirzah. (2008). Pengaruh level penggantian tepung ikan dengan limbah udang yang diolah dengan filtrat air abu sekam dalam ransum ayam buras. Jurnal Peternakan Indonesia.

North, M. O., \& Bell, D. D. (1990). Commercial Production Manual. (V. N. Reinhold, Ed.) (4th ed.). New York: Avi Book published.

Robinson, F. E., Wilson, J. L., Yu, M. W., Fasenko, G. M., \& Hardin, R. T. (1993). The relationship between body weight and reproductive efficiency in meat-type chickens. Poultry Science, 72(5), 912-922. https://doi.org/10.3382/ps.0720912
Savira, N., Yaman, M., Aman, \& Jalaluddin, M. (2018). Efek Pemberian pakan fermentasi dedak jagung, cangkang udang dan kepitng terhadap kadar kolesterol pada daging dada puyuh (Coturnix coturnix japonica) jantan. Jurnal Ilmiah Mahasiswa Veteriner, 2(2), 94-101. https://doi.org/10.21157/JIM VET..V2I2.6832

Subekti, S., Umarti, S., \& Murdiarti, T. B. (2008). Pengaruh daun katuk (Sauropus androgynus L. Merr) dalam ransum terhadap fungsi reproduksi pada puyuh. JITV , 13(3), 167-173.

Widyatmoko, H., Zuprizal, \& Wihandoyo. (2013). Pengaruh penggunaan corn dried distillers grains with solubles dalam ransum terhadap performan puyuh jantan. Buletin Peternakan, $37(2)$, 120-124. https://doi.org/10.21059/buletinpeternak. v37i2.2430

Wiradmadja, R. W., Piling, M. T., Suharto, \& Manalu, W. (2007). Umur dewasa kelamin puyuh betina yang diberi tepung daun katuk (Sauropus androgynous L.Merr). Jurnal Animal Production, 9(2), 67-72.

Zainuddin, S., \& Syahruddin. (n.d.). Pemanfaatan Tepung Keong Mas Sebagai Substitusi Tepung Ikan Dalam Ransum Terhadap Performa Dan Produksi Telur Puyuh. Universitas Negari Gorontalo, Gorontalo. 